\title{
STRAINS OF MICE FOR EXPERIMENTAL MURINE LEPROSY
}

\author{
PART 5. THE VALUE OF THE FIRST GENERATION HYBRIDS \\ OBTAINED BY CROSSING TWO INBRED STRAINS IN \\ EXPERIMENTAL MURINE LEPROSY - SELECTION \\ OF PARENTAL STRAINS FOR BREEDING
}

\section{Yoichiro KAWAGUCHI}

(The Institute for Infectious Diseases, The University of Tokyo)

The selection of the mouse strain adequate for murine leprosy experiments has been investigated in the series of previous papers. Through these experiments, it was found that $\mathrm{C} 57 \mathrm{BL}$ and $\mathrm{C} 3 \mathrm{H}$ strains were suited for the purpose. Since these two strains can not be easily maintained in a satisfactory condition, the author conducted the following experiments to find the mice which have similar properties to $\mathrm{C} 57 \mathrm{BL}$ and $\mathrm{C} 3 \mathrm{H}$ and more manageable than these inbred strains in breeding and feeding.

To meet these requirements, the author intended to establish a first generation hybrid (F 1) by crossing a male of a susceptible strain with a female of a manageable strain. Therefore, the selection of the parental strains for mating was carried out at first.

The susceptibility to subcutaneous inoculation with murine leprosy bacilli of mouse strains (C $57 \mathrm{BL} / 6, \mathrm{~A} 1, \mathrm{NC}$, dba, BALB/C, SM, C $3 \mathrm{H} / \mathrm{He}$ and $\mathrm{C} 3 \mathrm{H}$ ) was examined to select the male parental strain. As a result of this experiment, $\mathrm{C} 57 \mathrm{BL} / 6$ and $\mathrm{C} 3 \mathrm{H}$ strains were adequate for the purpose.

As the possible female parental strains, which are easier to breed, ddY and $\operatorname{ddD}$ were selected. In susceptibility to murine leprosy bacilli, ddY strain was found to be superior to ddD strain.

\section{鼠瀬の実験に用いるマウスの系統について}

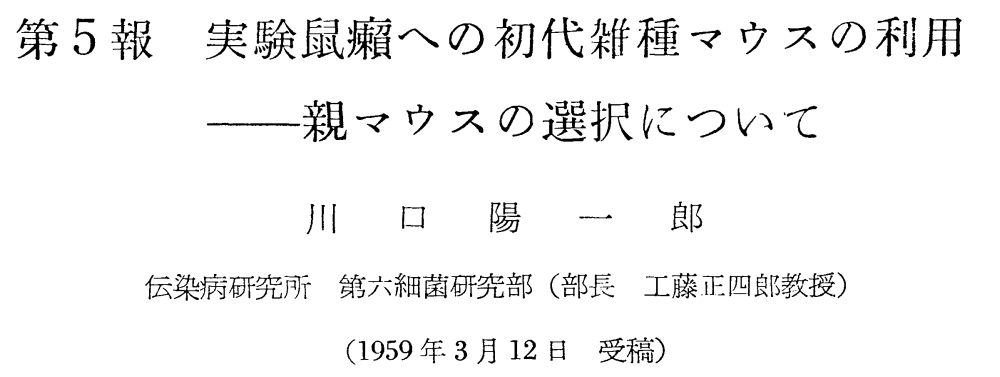

\section{緒 言}

近交系マウスに関する研究が進むにつれて, 鼠癩の実
験にもこ机を利用することが多くなつてきた。それにと もない，たんに近交系它使用するというにとどまらず， 各種の実験に夫々適当した系統を選び，これを用いよう 
とする傾向も生じてきた。

西村等1) は薬凪のスクリーニングに適当な系統として B系を推奖し，著者 ${ }^{2-3)}$ も各種のモデル実験に近交系、 ウスを使用した結果から，薬剤による発症阻止実験には $\mathrm{C}_{57} \mathrm{~B} \mathrm{~L}$ 禾が，治療実験及び免疫実験には $\mathrm{C}_{3} \mathrm{H}$ 采が夫々 最適であると報告した。

しかし，これ等の近交禾マウスは繁殖飼育がかなり困 難である上に，容易には手に入りがたく，実際にこれら を用いて実験を行うことはなかなかむつかしい。そこ で,これらの采統と同様な特徵をもち，しかも繁殖飼育 が容易なマウスが望まれるわけであり，これを見出すこ とが出来机ば, 鼠癩の実験は今よりも一層容易に, かつ 確実に行うことが出来ると考える。

また McLaren 等4) 注初代雑種は親の近交系よりもか えつて Bio-assay には使いよいといい, 螺良 ${ }^{5)}$ も $\mathrm{C}_{3} \mathrm{H}$ 禾 とdd系間の初代雑種は親の系統より移植癌の増殖に均一 な結果を示したと報告している。

このような点からみて, まず, 鼠攋菌に対して特徴あ る感受性をもつ系統と, 繁殖飼育が容易な禾統を選び, その間の初代雑種について, これらが求める性質をもつ マウスであるか, 否かを検討することにした。

ここに述べる成績は親マウスの選択についてである が，これは今迄の成績のみにもとずいて決定するのでは なく, 手に入れうる近交糸マウスの鼠攋菌に対する感受 性について検討し，その結果から親マウスを選択したも のである。

\section{I． 親雄マウスの選出について}

求める性質をもつ初代雑種を得るための親雄マウスに は, 鼠癩菌に対し極めて著しい特徽をもつ系統のマウス を選ぶべきであると考え，つぎの実験を行つた。

実験 I

各種近交系マウスの鼠癩菌に対する感受性

\section{実験材料および方法}

1. 使用マウス

$\mathrm{C}_{3} \mathrm{H}(\delta 6), \mathrm{C}_{3} \mathrm{H} / \mathrm{He}(\delta 7$ ), BALB/C ( $\delta 3$ ㅇ 4),

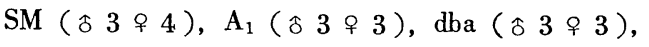

$\mathrm{NC}$ ( 호 2 ㅇ 2 ), $\mathrm{C}_{57} \mathrm{BL} / 6$ ( ㅇ 2 우 4 ),

以上 8 系統, すべて生後 5 週のもので, 伝研獣度研究 部繁殖室より入手した。

\section{2. 鼠癩菌接種}

使用菌株は八ワイ株，マウスに接種後20週目の皮下結 節を無菌的に摘出し，乳鉢でよく磨砕する。これに 100 倍量の生理食塩水を加えて後, 1000 r. p. m. で 10 分遠心 し，その上液を接種材料とした。
この接種用菌液（100倍乳剤とよぶ）の $0.25 \mathrm{cc}$ をマウ スの右腋窩部皮下に注射した。

なお，この菌液の 1 白金耳を $1 \mathrm{~cm}^{2}$ に塗抹, 染色, 鏡 検すれば， 1 視野に平均 3000 前後の菌を認める。

3. 飼育方法

マウスは各尙統別に, かつ雌雄別にして飼育し, 飼料 としては繁殖用固型飼料と水を与えた。

4. 成績判定法

鼠癩菌接種後, 2 週目ごとに16週目まで, 接種部位に おける結節の抎がりを観察した。

判定は既報6) の規準により，結節指数の平均をとり図 示した。

\section{実験成績}

成績は図 1 に示した通りである。

困 1 各種近交系マウスの鼠攋菌に対する感受性

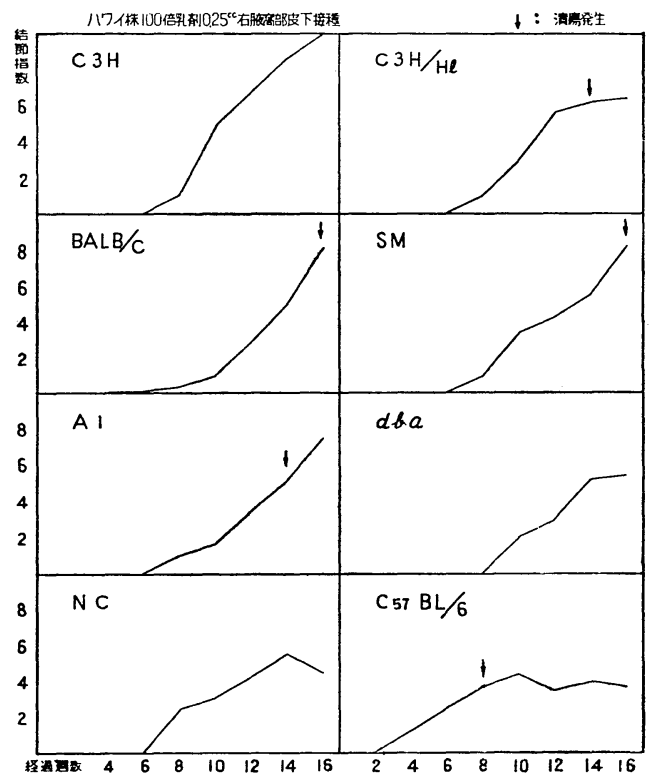

系統別にその特徴を略記すれば，

$\mathrm{C}_{3} \mathrm{H}$ 系：結節を触れる時期は迤く, 明膫に触れるの は10週以後であるが, 徐々にその大きさを増し, 16週に は拇指頭大に達する。また，この間に潰瘍は認められな W。

$\mathrm{C}_{3} \mathrm{H} / \mathrm{He}$ 系：結節触診所見は 12 週迄は殆んぞ $\mathrm{C} 3{ }_{3} \mathrm{H}$ 禾と 差がない。しかし, 以後あまり大きさは増さず，14週で 小指頭大であり，16週でも示指頭大のものが最大であつ た。謴瘍を生じた例も少数ながら認められた。

$\mathrm{BALB} / \mathrm{C}$ 系： 8 週で結節を触れる例もあるが, はじめ は極めて小さい。結節の大きさは極めて徐々に増し, 16 週には示指頭大に達した。また16週には潰瘍を生じた例 
があつた。

S M禾：結節増大の経過は $\mathrm{C}_{3} \mathrm{H}$ 杀とよく似ているが， その大きさは16週でも示指頭大程度で, 潰瘍を生じた例 もあつた。

$\mathrm{A}_{1}$ 系：結節を触れる時期は $\mathrm{C}_{3} \mathrm{H}$ 杀とほぼ同じである が, 大きさ注小指頭大より示指頭大でつて, 14週より潰 瘍を生じた例があつた。

dba 系：結節を触れる時期は極めて遅く, 10 週から触 れだす。大きさもあまり増加せずほぼ小指頭大である。 観察期間中に潰瘍をみた例はない。

N C 系：結節を触れる時期はやや早く，8週から明瞭 に触れるが，大きさはあまり増さず小指頭大に達しな い。潰瘍を生じた例はなかつた。

$\mathrm{C}_{57} \mathrm{~B} \mathrm{~L} / 6$ 系：結節を触れる時期は極めて早く，4 週 から触れ出し，6週で全例に触れるが，10週以後でも小 指頭大をこえることはない。潰瘍を生ずることも早く， 8 週からみられ，10週には殆んど全例に潰瘍がみられ る。

表 1 各系統の特徵の比較

\begin{tabular}{|c|c|c|c|c|c|c|c|c|}
\hline 系 統 名 & $\mathrm{C}_{3} \mathrm{H}$ & ${ }_{\mathrm{He}}^{\mathrm{C}} \mathrm{H} /$ & $\left|\begin{array}{r}\text { BALB } \\
/ \mathbf{c}\end{array}\right|$ & SM & $A_{1}$ & $\mathrm{dba}$ & $\mathrm{NC}$ & $\mathrm{c}_{57} \mathrm{BL} / 6$ \\
\hline 結節発生の早さ & + & + & H & + & + & + & H & H \\
\hline 結節の大きさ & \# & H & H & H & H & + & + & + \\
\hline 溃呁発生の遅さ & m & H & H & H & H & H & m & + \\
\hline
\end{tabular}

結 節 発 生: 早く触れるもの $+\cdots+\cdots \cdot \cdots \cdot$. 遅く触れるもの+ 結節の大きさ：大 結 節 $\#+\cdots \cdots$...... 結 節 +

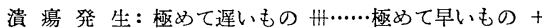

以上の関係を一括して示せば表 1 の通りである。この 成績からみると $\mathrm{C}_{57} \mathrm{~B} \mathrm{~L} / 6$ 系は結節を触れる時期は最も 早いが，潰瘍を生じやすく，結節も大きくならない。 $\mathrm{C}_{3} \mathrm{H}$ 系は結節を触れる時期は遅いが，その大きさは最 大であり潰瘍を生じ難い。このように上記の禾統は対蹠 的ではあるが著しい特徴を示し, 他の系統はみなこの中 間の性質をもつことが分つた。

\section{II. 親雌マウスの選出について}

親雄には特徵のある感受性をもつ系統が望まれるが, 親此倠はこれと異り, 繁殖飼育が容易であり, しかも比較 的容易に入手出来る系統のマウスでなければならない。 この条件に適するものとしてはdd系があげられる。

しかしdd系には业系があり，夫々幾分異つた性質をも つように思われるので，つぎの実験を行つた。

実験 II dd秃亜亲間の鼠癩菌に対する感受性の相違

実験材料および方法

1. 使用マウス

dd-D系 古 生後 4 週

伝研獣疫研究部dd繁殖室より入手した。 dd-Y系 9 生後 4 週

予研獣度部より入手した。

\section{2. 鼠癩菌接種}

使用菌株はハワイ株，マウスに接種後16週目の皮下結 節より，実験Ｉ と同じ方法で生理食塩水を用いて，100 倍及び1000倍乳剤を作り，その0.25ccずつを夫々マウス の右腋窩部皮下に注射した。マウスは 1 群各 8 匹であ る。

また，この 100 倍乳鼡中の菌数は実験 I に用いた菌液 の菌数とほぼ同じである。

3. 飼育方法

実験 I とほぼ同様で，この場合は普通固型飼料と水で 飼育した。

4. 成績判定法

成績の判定方法は実験 I とほぼ同じで，今回はマウス 個々の結節所見をも記載した。

実験成績

成績は図 2 及び図 3 に示した。

100 倍乳剂接種例についての成績は図 2 に示す通りで あつて, dd-Y 系の方に結節を早く触れる例が多く, 8 週目にはdd-Y系の全例に, 10週目にはdd-D采の全例に

2 図 dd系覀禾の鼠攋菌に対する感受性（I） 100 倍乳刘接種例

\begin{tabular}{|c|c|c|c|c|c|c|c|c|}
\hline W & \multicolumn{5}{|c|}{ dd - D 系 } & \multicolumn{2}{|c|}{ 우 } & \\
\hline 6 & $\perp$ & - & - & - & - & - & - & - \\
\hline 8 & + & $\perp$ & $\perp$ & $\perp$ & $\perp$ & $\perp$ & - & - \\
\hline 10 & $H^{1}$ & H & H & +1 & + & H & + & + \\
\hline 12 & $\oplus$ & 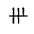 & $H^{\prime}$ & $H$ & + & + & + & + \\
\hline 14 & (冊) & (丹) & $\bigoplus$ & 世 & $H^{\prime}$ & $H$ & H & \\
\hline 16 & (\#) & $\oplus$ & 世 & H & 世 & H & H & \\
\hline W & \multicolumn{5}{|c|}{$d d-Y$ 系 } & \multicolumn{2}{|c|}{ 우 } & \\
\hline 6 & + & + & + & $\perp$ & $\perp$ & $\perp$ & $\perp$ & - \\
\hline 8 & H & H & + & H & H & + & + & + \\
\hline 10 & H & $H$ & $\#$ & H & $H$ & $H$ & + & $t$ \\
\hline 12 & HI & HH & m & $H$ & H' & $H$ & H & H \\
\hline 14 & H & m & H & $H$ & $H$ & 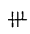 & $H$ & $H$ \\
\hline 16 & W & m & HI & $H$ & "II & \# & $H$ & $H$ \\
\hline
\end{tabular}




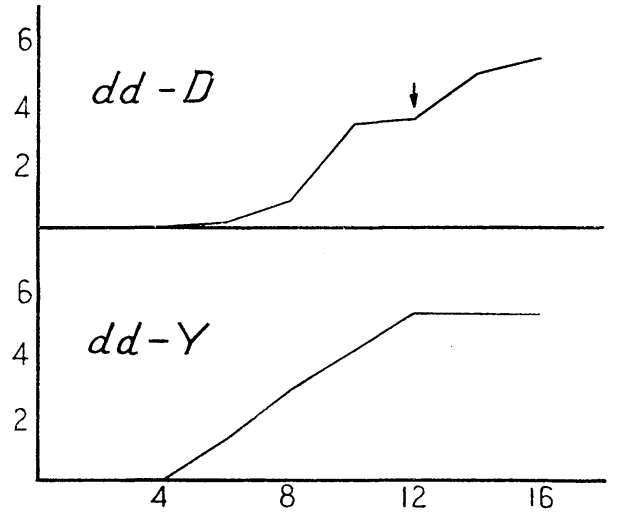

図 3 dd系亜系の鼠癩菌に対する感受性（II） 100 倍乳剂接種例

\begin{tabular}{|c|c|c|c|c|c|c|c|c|}
\hline W & \multicolumn{5}{|c|}{ dd $-D$ 系 } & \multicolumn{3}{|c|}{ 우 } \\
\hline 6 & - & - & - & - & - & - & - & \\
\hline 8 & $\perp$ & $\perp$ & - & - & - & - & - & \\
\hline 10 & $\mu$ & + & $\perp$ & $\perp$ & $\perp$ & $\perp$ & $\perp$ & \\
\hline 12 & H & H & + & $H$ & + & $\perp$ & $\perp$ & \\
\hline 14 & 巴 & H & H & + & + & + & $\dot{-}$ & \\
\hline 16 & 曲 & $H^{\prime}$ & H & $H$ & + & + & + & \\
\hline $\mathrm{w}$ & & \multicolumn{4}{|c|}{$d d-Y$ 系 } & \multicolumn{2}{|r|}{ 우 } & \\
\hline 6 & - & - & - & - & - & - & - & - \\
\hline 8 & $\perp$ & $\perp$ & $\perp$ & - & - & - & - & - \\
\hline 10 & $\mu$ & + & + & + & + & $\perp$ & $\perp$ & $\perp$ \\
\hline 12 & $\#$ & \# & H & H & H & $H$ & $t^{\perp}$ & $H$ \\
\hline 14 & H & 世 & $H^{1}$ & H & $H$ & $H$ & + & H \\
\hline 16 & 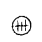 & H & $\#$ & $\Psi$ & H & H & H & H \\
\hline
\end{tabular}

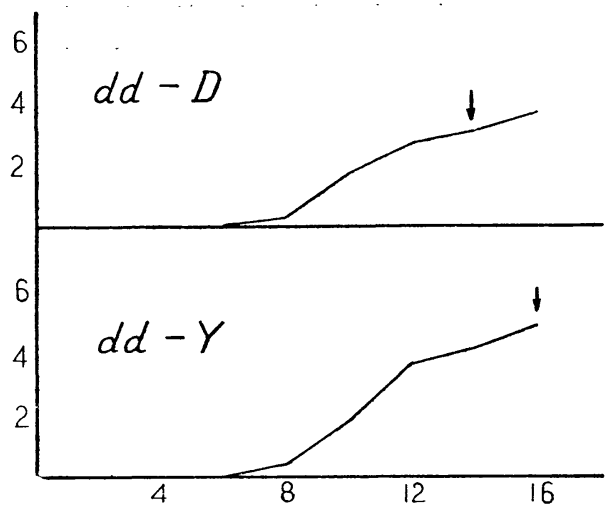

結節を触れるようになるが，この時期では結節の大きさ は dd-Y 系の方がわずかに大きい。その後も徐々に大き さを増すが, dd-Y 系は 12 週が限度で以後あまり変化が ない。一方 dd-D 系は僅かながら増加するように思われ る。しかし大きさはほぼ小指頭大で示指頭大に達するも のはなく，両系の間にとくに差はない。ただ個体差はdd ーY 系の方が少なかつた。

また dd-D系の 2 例に潰演がみられたが，dd-Y系では 脱毛は著しいが観察期間中に潰湯をみた例はなかつた。

つぎに，1000倍乳鼡ついて述べる。成績は図 3 に示し た通りで，両系間には大差がない。

結節を触れる時期，その大きさ，潰癔出現の時期等, とくに差のある点はなく, dd-Y 系の方が，この場合も dd-D 系より個体差が僅かに少いように思われた。

以上の点からみて, 感受性のみの比較では親䧳として どちらを選んでも大差はないが，個体差の少い点から， dd-Y 系を選ぶ方が良いように思わ机る。

\section{総括ならびに考按}

$\mathrm{C}_{57} \mathrm{~B} \mathrm{~L}$ 系及び $\mathrm{C}_{3} \mathrm{H}$ 系が鼠瀨の実験に適する系統であ ることは既に報告したが，これらはともに繁殖飼育が容 易でなく，また入手することも困難である。それ故これ に代るものとして，これらと同程度の性質をも台，しか も繁殖飼育が容易なマウスを得ようと考えた。

この目的に適するマウスとしては，前にも述べたよう に，初代雑種が適当と思い，まずその親マウスを選びだ すことにした。

求める性質の一つとして繁殖飼育が容易である必要が ある。この条件を充すためには, 親雌がこの条件に適し なければならない。したがつて鼠癩菌に対して特徴ある 感受性をもつ系統が親雄として用いられることもまた当 然のことになつて来る。

まず，親雄に適した柔統を選ぶ目的で行つたのが実験 Iである。

鼠瀨の実験に適する特徵ある感受性をもつ系統として $\mathrm{C}_{57} \mathrm{~B}$ L系と $\mathrm{C}_{3} \mathrm{H}$ 系をあげておいたが，この場合に検討 した近交系は総計 6 系統に過ぎかつた。そこで今回は 未だ検討されていない 6 系統に，対照として $\mathrm{C}_{57} \mathrm{~B} \mathrm{~L} / 6$ 系及び $\mathrm{C}_{3} \mathrm{H}$ 系を加えて，これらの鼠癩菌に対する感受 性について検討した。

この実験においても $\mathrm{C}_{57} \mathrm{~B} \mathrm{~L} / 6$ 系と $\mathrm{C}_{3} \mathrm{H}$ 系は夫々対䟢 的ではあるが，きわめて著しい特徵を示し，他の 6 系統 はこの両采の中間の性質をもつことが分つた。

結核菌に対する感受性は，有色系マウスの方が白色禾 よりも強いといわれており，著者も既報6) の実験成績か 
ら鼠癩菌に対する感受性の点で, 有色杀マウスに著しい 特徴を認めた。それ故にこの実験では $\mathrm{C}_{3} \mathrm{H} / \mathrm{He}, \mathrm{N} \mathrm{C}$, $\mathrm{A}_{1}$ ， dbaの有色系 4系統を加えてみた。しかし，こ机ら は他の白色系 BALB/C, SM 両系に比較してとくに著し い差があるとはいえなかつた。毛色と感受性の間にとく に関係があるとはいえないようである。

いずれにせよ，この実験で親雄としては $\mathrm{C}_{57} \mathrm{~B} \mathrm{~L} / 6$ 系 及び $\mathrm{C}_{3} \mathrm{H}$ 禾が最適であると考える。

つぎに親雌についてであるが，比較的容易に入手出来 て，しかも繁殖飼育が容易な系統としてまず考えられる ものはdd系をおいて他にない。

しかしdd系には亜系があり, 亜系間の鼠癩菌に対する 感受性の相違については未だ検討されていない。そこで 容易に入手しうる dd-D 系と dd-Y 系について, この点 を検討したのが実験IIである。

実験IIの成績からみると, 覀禿間には僅かながら感受 性に差のあることが分る。 dd-Y 系は dd-D 系より結節 を早く触れ，個体差も少いようである。この成績の夕で はとくにどちらが良いとはいえないが， dd-Y 系がやや 勝れているものと思わ礼る。しかしdd 系は近交系では なく均一系として知られているものであるから, 親雌と しての優劣の決定は更に交配を行つた結果を参考とし て，今一度検討する必要があろう。

\section{結語}

鼠瀨の実験に適する系統としてあげた近交系マウス
は，いずれる繁殖飼育が困難であり，また入手し難い点 もあつて，これらを用いて実験を行うことは比較的に困 難である。それ故にこれら近交系マウスと同様な性質を もち，乙办も容易に入手出来て，手数もかからないマウ スが望まれるわけである。

この目的に適するものとして鼠瀨菌に対して著しい特 徵をもつ禾統と，繁殖飼育が容易な系統との交配により えられる初代雑種について検討することとし，まず親マ ウスの選択を行つた。

この結果から, 親雄としては $\mathrm{C}_{57} \mathrm{~B} \mathrm{~L} / 6$ 禾及び $\mathrm{C}_{3} \mathrm{H}$ 杀 が適当であり，親䧳としては dd-Y 系が適当であろうと 思われる。

（終りに御指導御校閲を頂いた工藤教授，御協力下さつ た獣疫研究部奥木氏，予研笠松技官に梁く感謝する）

\section{文献}

1）西村, 岩佐：レプラ, 24405 (1955)

2) 川ロ: レプラ, 27 44 (1958)

3）川ロ: レプラ, 2749 (1958)

4) McLaren, A. \& D. Michie : Nature, 173, 686 (1954)

5）螺良：実験動物，6 65（1957）

6) 川ロ:レプラ, 26 318 (1957)

27 巻 1 号（第 2 報及び第 3 報）の正誤表

\begin{tabular}{|c|c|c|c|}
\hline 訂 & 所 & 誤 & 正 \\
\hline 27巻 44 頁 & 本文左 4 行目 & 鼠癩り実験 & 鼠癩の実験 \\
\hline " 45 頁 & $\begin{array}{l}\text { 左37行目以下に挿 } \\
\text { 入 }\end{array}$ & （右項脱落） & $\begin{array}{l}\text { 攻撃法：各系マウスを更に } 2 \text { 群に 分け, 前記の 乳剤を } \\
0.3 \mathrm{cc} \text { ずつ夫々の右放窩部皮下に接種した。 }\end{array}$ \\
\hline " 46頁 & 右下上り 2 行目 & 免癩群 & 免疫群 \\
\hline " 49頁 & 英文抄録著者所属 & lastitute & lnstitute \\
\hline$"$ & 英文抄録 2 行目 & administion & administration \\
\hline & 4 行目 & determinarion & determination \\
\hline
\end{tabular}

